All Politics is Still Local:

McConnell vs. Lunsford in the 2008 Kentucky Senate Race

\title{
Jasmine Farrier
}

The guy running against me, if he was successful, would be a rookie. Do you want to send Kentucky to the back bench with little or no influence?

$$
\text { -Sen. Mitch McConnell }{ }^{1}
$$

I'm running to restore the American dream and the opportunities I had as the son of a union laborer who grew up to become a Fortune 500 CEO. Mitch McConnell and George Bush have stood in the way of working families, and it is time for a change.

-Challenger Bruce Lunsford ${ }^{2}$

\section{Introduction}

The political drama of the 2008 re-election of Mitch McConnell was not his eventual fifth victory, which was predictable, but the fact that he won by only six percent of the vote. Senator McConnell spent over \$20 million (including \$2 million in final-stretch loans) to defend his seat against a selffinanced businessman who spent $\$ 11$ million and had never held an elected post. The fact that this race was the second most expensive in the country in 2008 suggests that the seat was in real danger for the first time in decades and McConnell knew it (see Jacobson 1980, 1985). His first two elections in 1984 and 1990 were very close, but as he ascended in statewide and national prominence his next two elections in 1996 and 2002 were landslides. While 2008 had special twists, this type of sudden vulnerability was not unique to Senator McConnell. In fact, this "bumpy-smooth-bumpy" electoral trajectory happens in many congressional careers. Paul Herrnson writes, "[a]lthough incumbents generally derive tremendous advantages from the strategic environment, the political setting in a given year can pose obstacles for some, resulting in significant numbers losing their seats" $(2004,29)$.

JASMINE FARRIER is an associate professor of political science at the University of Louisville.

The American Review of Politics, Vol. 30, Summer, 2009: 155-172

(c)2009 The American Review of Politics 


\section{6 | Jasmine Farrier}

Using public data, media reports, and interviews with six people knowledgeable about the race (two closely involved with Kentucky Republicans and Senator McConnell, two with Democrats and Lunsford, and two veteran statewide political reporters), I argue that McConnell versus Lunsford was a meaningful contest for many reasons that spring from Kentucky's complex political environment but also transcend it. On the one hand, the election appears to be a straightforward story about the power of incumbency, political demographics, and maintaining large war chests. Looking deeper, McConnell's re-election highlights how Senators balance their responsibilities - statewide representative of diverse interests, national policy maker, and partisan - and communicate their choices to voters when these duties come into conflict. ${ }^{3}$ This article shows how and why McConnell emphasized the first as well as how the opposition failed to exploit his vulnerabilities in the latter two. The full story has several interconnected components, two of which centered on McConnell and two on the state's political environment.

The first and most important aspect of the election was Senator McConnell's strategic use and communication of his political position. Senator McConnell's defense during the "year of change" turned the recession and accompanying anti-Republican tide on its head. His main argument was that the Commonwealth would benefit from his power and prestigeregardless of who won the White House and which party held the majority in Congress. In this way, McConnell turned his main liability-being a key member of the Republican Washington establishment - into an asset by distancing himself from President Bush, Republicans in Congress, and his own party's presidential candidate, all while maintaining and promoting his stature as the most important Republican in Congress in 2008 (and probably the most important Republican in all of Washington in 2009). While John McCain campaigned against federal spending earmarks during his presidential run, McConnell touted his efforts to deliver benefits to his constituents in detail, with the underlying message that the Senator put Kentucky first. ${ }^{5}$

Second, Senator McConnell is a prodigious fundraiser and fierce campaigner known for attacking challengers on personal and political vulnerabilities. McConnell has a reputation in Kentucky for defining his opponents negatively early and 2008 was no different. McConnell asked, "Who is Bruce Lunsford?" and made Lunsford's business success, personal wealth, and homes in multiple states all look to be mysterious and non-representative of Kentucky's interests. ${ }^{6}$ Bruce Lunsford was not able to overcome this negativity despite the fact that Senator McConnell's own approval fell throughout the fall as the economy worsened and Republicans nationally (including John McCain) suffered one political blow after another. ${ }^{7}$ Using television ads tailored to each part of the state, direct mail, and a two week 
final bus tour making over 60 campaign appearances in small towns, McConnell defended his unique position in Washington, while keeping the heat on Lunsford and repeatedly saying that only he knows how to deliver.

Third, Senator McConnell did not have to worry about an Obama coattail effect and probably benefited in reverse. With a relatively low African-American population (about 7\%) and widespread assumption of racism among Kentucky's white rural voters, it was a commonplace observation that Bruce Lunsford suffered by being one spot below Barack Obama on the ballot instead of Hillary Clinton (who won the Kentucky primary easily in May of 2008). Still, according to the interviews and election data, Kentucky is more maroon than red and has complex split-ticket tendencies that put more emphasis on the person and office than the party. While McConnell would have had a tougher re-election with a more popular Democrat on top of the ballot in 2008, Kentucky's political culture allowed him to be judged on his own merits, outside the state and national party environment that was increasingly hostile to Republicans. McConnell has become, in the words of several political insiders, "his own institution."

Fourth, Bruce Lunsford did not provide the strongest possible threat to Senator McConnell. He had personal wealth to fund television ads and name recognition after his previous unsuccessful runs for the Democratic gubernatorial nomination in 2003 and 2007, but Lunsford was not known for any specific policy stances and had an uncomfortable relationship with statewide Democrats after he endorsed the Republican nominee in the general election in 2003. Lunsford nevertheless won the 2008 Democratic primary and the support of state and national Democrats mostly due to his ability to pay for his own campaign. Apparently, more established Kentucky Democrats were waiting until the more vulnerable Senator Bunning ran for re-election in 2010. As a political outsider, Lunsford was more comfortable discussing President Bush's tenure and his own business history than specific policy stances. For example, Lunsford failed to exploit McConnell's unwavering support for the October 2008 Wall Street bailout, which was not popular in Kentucky. Even Lunsford's own strategists said he did not know how he would have voted on the legislation. Lunsford tried to paint Senator McConnell as being tied to Bush's hip, but such efforts were undermined by McConnell's party separation strategy. Research on congressional elections shows that high levels of partisan voting in Congress often results in a potent strategy for challengers in certain circumstances (Carson 2005). According to strategists on both sides, 2008 was the most favorable political environment for Democrats to win McConnell's seat but Lunsford was not the person to do it. 


\section{Public Opinion and Politics in the Bluegrass State}

In many ways, Kentucky is square in the demographic mainstream of the current Republican Party. However, Kentucky is split internally, like other Midwestern and Southern states, between urban and rural voters, with the latter favoring Republicans by increasing margins and the reverse being true in the cities. In 2008, Senator McConnell lost the counties that contained the biggest cities in Kentucky, Louisville and Lexington, the latter for the first time. Barack Obama won both of those counties. Yet as a state, Kentucky is closer to the contemporary averages of the Republican Party on a variety of "culture war" issues in recent decades. Almost 37 percent of Kentucky's population describes itself as "evangelical Protestant," which places the Commonwealth sixth highest in the nation (Arkansas leads with $43 \%$ and Rhode Island is last with $1.5 \%){ }^{8}$ In a separate aggregate 20042006 Gallup poll report, Kentucky ranked 12th in the nation for church attendance, with 48 percent responding that they attend once a week or almost every week. ${ }^{9}$ Kentucky public opinion is very close to the Republican National Committee's (RNC) "Values" platform on abortion, gay marriage, and guns. ${ }^{10}$

At the same time, while Kentucky is not a high profile "swing state" and was not courted heavily by presidential candidates in 2004 and 2008, it has shown complex electoral patterns since the 1970s. On the presidential level, Kentuckians preferred fellow southerners Carter and Clinton but have otherwise leaned Republican beginning with Nixon. Yet Kentucky is still considered a Democratic state for its statewide registration figures: 57 percent to the Republicans' 36 percent. Kentucky also only elected a single, one-term Republican governor from 2003-2007 after decades of Democrats. For the past 10 years, the state legislature has been split with the state Senate dominated by Republicans, and the state House of Representatives dominated by Democrats. ${ }^{11}$ Democrats have been on the rebound since 2007 with the election of Democrat Governor Steve Beshear and a party sweep of independently elected cabinet offices. ${ }^{12}$

While the causes and evidence of split ticket voting decisions are complex (see for example Karp and Garland 2007) these different national and statewide electoral results in Kentucky show a "maroon," not "red" state, which the political strategists and analysts agreed force statewide candidates to work harder and more personally for votes. For example, in 2004, George W. Bush won Kentucky by 20 percent over John Kerry and voters went 3:1 in favor of a gay marriage ban in the state Constitution, but Kentucky's junior Senator, Jim Bunning, also a conservative Republican, won re-election by just 2 percent against a little-known Democratic state senator. While a less dramatic difference in 2008, John McCain won almost 300,000 more 
votes than Barack Obama (57\% to 41\%). Senator McConnell's victory, however, was just a third of that margin, with almost 107,000 votes more than Lunsford (53\% to $47 \%)^{13}$

\section{Electoral and Political Context of the 2008 Election Cycle}

McConnell's sudden vulnerability had little to do with statewide issues. He would not have been challenged as effectively as he was in 2008 if the Republican Party and President Bush were not held so low in popular opinion. There was no particular scandal at home involving Kentucky's senior Senator and there was no widespread sense that other than being a Republican in a bad moment for Republicans that he was a bad "fit" for Kentucky. In Kentucky, President Bush's approval rating declined steadily from 20052008. His monthly approval rating hovered in the high to low 40s in 2005, the low 40s to high 30s in 2006, and then stayed in the 30s for both 2007 and 2008 , with the exception of two months that reached 41 percent approval. ${ }^{14}$

In 2008, it seems Kentucky voters punished Senator McConnell more than Senator McCain for being a Republican loyal to the signature policies of President Bush. In 116 out of 120 counties in Kentucky, McConnell won by a smaller margin than McCain. At the same time, according to the state party political strategists and news analysts interviewed, McCain's high margin of victory did not imply high levels of support for him personally or the party but rather fear and distrust of Barack Obama. Both McCain and McConnell struggled to distance themselves from President Bush and their burdens had different origins and consequences for the election. All six insiders agreed that McConnell's position as party leader made his floor votes and public rhetorical support crucial to the President's legislative goals for both terms. The trick for McConnell was temporarily divorcing himself from this policy loyalty that enabled him to climb the party ladder and convince voters that the Commonwealth was always his first priority.

\section{The Incumbent: Mitch McConnell}

Senator McConnell was not dragged into politics. He said the night of his 2008 election that "[c] ampaigns like this force you to work harder, and they remind you what a privilege it is to serve. But public service has always been a special privilege for me. Growing up, most kids want to be baseball players. I wanted to be a U.S. Senator."15 Addison Mitch McConnell, Jr. was born in Alabama but was raised and educated in Kentucky. McConnell showed early political ambition by winning three positions as some form of student body president: in high school in Louisville, in the College of Arts and Sciences at the University of Louisville, and then president of the 
Student Bar Association at the University of Kentucky Law School. After he completed law school, McConnell worked for two liberal/moderate Republican Senators from Kentucky: John Sherman Cooper and Marlow Cook. McConnell then became a deputy assistant attorney general under President Gerald Ford. His first elected position in Kentucky was serving as County Judge-Executive in Jefferson County, which includes Louisville - the state's most populous and liberal county-from 1978 to 1984. McConnell's two Senate mentors also held this once-powerful post (now defunct due to county government reorganization). ${ }^{16}$ The real start of McConnell's career was of course in 1984, when he squeaked ahead of two-time Democratic Senate incumbent Walter "Dee" Huddleston by less than one-half of one percentage point and became the first Republican to win a Senate seat from Kentucky in almost twenty years. ${ }^{17}$

Over two and a half decades in the Senate, McConnell went up the ranks on the Agriculture, Nutrition and Forestry, and Appropriations Committees as well as the party leadership ladder. In 2002, he was elected Majority Whip (also called Assistant Majority Leader) and after the 2006 election he was promoted to Minority Leader, which he retained after the 2008 election. Among other national policy stances, he supported agricultural policy, especially federal payouts for tobacco farmers' transition into other crops, and appropriations for Kentucky's universities, infrastructure, and community centers across the state. ${ }^{18}$ In Washington, McConnell has long been considered a conservative Republican motivated by an ambitious pragmatism rather than ideological fervor on any one issue. During the Bush years, McConnell voted with his party on most culture war issues, taxation, and the War on Terror, but never wavered from bringing home federal dollars (even while repositioning himself as a deficit hawk in 2009). ${ }^{19}$

\section{The Challenger: Bruce Lunsford}

Bruce Lunsford is a Kentucky native who lived in-state most of his life and, like McConnell, earned degrees from its public institutions: the University of Kentucky for undergraduate and Northern Kentucky University for his law degree. In the late 1970s, Lunsford was active in the state Democratic Party as Treasurer and had high-profile roles in the campaign and administration of Democratic Governor John Y. Brown Jr., who remained close to the candidate in 2008. Lunsford was appointed by Brown as the state's first Commerce Secretary and had a large hand in developing the Northern Kentucky airport near Cincinnati as a Delta hub revitalizing that region of the state. Lunsford is also a CPA, who in the 1980s founded a large nursing home and health care company, currently known as Kindred Healthcare. 
While no longer owned by him, this company's history in its earlier forms proved a consistent burden when Lunsford decided to enter politics. In the late 1990s, Lunsford's company, then known as Vencor, did not admit wrongdoing but engaged in a complex federal civil settlement of over $\$ 100$ million dollars for allegations involving overbilling of Medicare and other issues related to its Chapter 11 bankruptcy. Meanwhile, throughout this time, Lunsford gave millions to both Democratic and Republican Party candidates and committees, which probably did not help him win over the Democratic establishment. At the time he ran for Senate in 2008, Lunsford's current business interests were less controversial, including a private investing firm, horse racing, and independent film production. ${ }^{20}$

While Lunsford had no discernible record as a policy advocate, in 2003 Lunsford ran in the Democratic gubernatorial primary and spent about $\$ 8$ million of his own money. This action raised eyebrows, but not as much as his other activities. First, after Democratic rival Ben Chandler, then-state Attorney General and son of a former governor, raised the Vencor settlement issues in an ad campaign, Lunsford dropped out at the last minute and endorsed Democrat Jody Richards, speaker of the State House. Chandler won the primary and Lunsford then endorsed the Republican nominee, Congressman Ernie Fletcher, who won in November. Lunsford then served on Fletcher's transition committee. In interviews and media accounts, this "betrayal" of Democrats in 2003 is considered Lunsford's main "baggage" - even more so than his complex heath care businesses.

In 2007, three Democratic tickets of Governor/Lieutenant Governor contested the primary and Lunsford's ticket came in second. Lunsford's partisan loyalties were considered thin and malleable by some Democrats and Republicans that year, based on his behavior four years earlier and the fact that the same Republican Governor Fletcher was running for reelection. ${ }^{21}$ The winner of the 2007 primary, Steve Beshear went on to beat Fletcher in November. In 2008, the primary choice was mainly between Lunsford and a lower-profile Democratic businessman who had more establishment support; Lunsford won with 51 percent. $^{22}$

As the epigraph implies, Lunsford's campaign tried to paint his personal and business history as a Horatio Alger-esque story of rags to richesa blue collar and agricultural family produced an entrepreneurial success that benefited Kentucky. McConnell, however, painted Lunsford's complex business interests as being built on greed and ethical lapses. McConnell's campaign also tried to portray Bruce Lunsford as a wealthy outsider, highlighting his homes and business ventures outside of Kentucky. ${ }^{23}$ Despite his rocky relations with other prominent Democrats, Lunsford tried to minimize these liabilities by being endorsed by the state's four previous Democratic governors in a television ad touting his job creation in Kentucky. ${ }^{24}$ 


\section{Strategies and Tactics in the Campaign}

Senator McConnell's first line of attack was part of a long-held strategy to define his opponent. Lunsford tried from the beginning of the race to define himself as a successful person who rose on his own pluck from cutting tobacco on the family farm in Kentucky as a child and putting himself through college laying blacktop. ${ }^{25}$ Lunsford's portrayal of himself as a populist was in constant competition with McConnell's repeated description of him as a wealthy and shady mystery man. ${ }^{26}$ In a surprising attack ad that focused on the lesser-known spin-off of Lunsford's health care company, Vencor, McConnell accused Lunsford of neglecting veterans' medical care. This dramatic and negative image stuck. ${ }^{27}$ Strategists on both sides said McConnell did not need to, or care to, exploit other business vulnerabilities of Lunsford's related to the late 1990s bankruptcy and federal civil suit, in part because McConnell's wife Elaine Chao sat on one of those company's boards.

In late 2007, national antiwar groups began airing ads against Senator McConnell's support for President Bush and the Iraq war. ${ }^{28}$ Bruce Lunsford attacked Senator McConnell most consistently on his close connection to the national Republican Party and the policies of outgoing President George Bush - both obvious targets in 2008. These lines of argument were the most important and successful of Lunsford's race, according to all the sources interviewed. He was less successful in challenging McConnell's assertions about his appropriations prowess; Lunsford tried to that argue he could deliver more federal money and services to Kentucky than McConnell and that McConnell overstated the amount of federal dollars he brought to Kentucky. Those interviewed all agreed this strategy did not work.

Those interviewed also added that they were surprised that Lunsford did not successfully exploit McConnell's clear help for President Bush in securing the first finance industry bailout in October 2008, which was not popular in Kentucky. According to a Rasmussen poll, Lunsford was supported by 61 percent of voters who rated the economy as the top issue in the fall election. ${ }^{29}$ As said earlier, part of the reason for Lunsford's tepid response was, according to sources on both sides of the race, that he did not articulate his own position on the bailout and seemed privately and publicly unsure how he would have voted had he been in the Senate. In a television ad, for example, Lunsford alluded to this issue as well as the conviction of McConnell's close colleague Sen. Ted Stevens, but did not hit them very hard. ${ }^{30}$ In the end, Lunsford's arguments and strategies failed to undermine McConnell's main argument of being deeply useful to Kentucky. McConnell was not just President Bush's "water boy" in the words of one political reporter, he was "his own political institution." Under some political condi- 
tions, this description would be a liability, but that argument did not stick in 2008. At the same time, exit polls in Kentucky show that on several questions related to the economy, the worse people saw the situation the greater the support they had for Bruce Lunsford. Those who were most worried about terrorism and the war in Iraq had greater support for Mitch McConnell. ${ }^{31}$

\section{Campaign Themes and Communication Strategies}

McConnell's campaign was primarily about his own strengths and secondarily about Lunsford's weaknesses. As said earlier, McConnell tailored several similar television ads to each part of the state to explain how much and where the money went to benefit Louisville, Central Kentucky, and Northern Kentucky. Lunsford's campaign was also primarily focused on McConnell - specifically the latter's relationship to the national Republican Party and President Bush's signature policies. Despite the prickly relationship Lunsford had with some prominent Democrats in Kentucky based on his previous races, he gained endorsements from four former Democratic governors and made several appearances with important Democrats, such as Louisville-area congressman John Yarmuth and Mayor Jerry Abramson, as well as state attorney general Jack Conway, all of which are not particularly well-known or liked by rural voters. ${ }^{32}$

Lunsford was not the central point of 2008 even within his own campaign - the battle cry of the Democrats was "Ditch Mitch." Jennifer Duffy, of the nonpartisan Cook Political Report, reported that Lunsford was the fourth or fifth choice of statewide Democrats for 2008, but only Lunsford had the personal funds to make the race interesting. ${ }^{33}$ One Kentucky Democratic insider who was a field organizer for Lunsford said that there was not much love lost between Lunsford and his soldiers in the field. This person personally expressed his/her own dislike for Lunsford as a candidate and described the campaign manager Bradley Katz's strategy of "A.A."-Lunsford was an "acceptable alternative" to McConnell and should be presented as such to voters. A Republican strategist involved in the McConnell campaign said he/she noticed at opposition rallies there were seas of "Ditch Mitch" t-shirts and signs - not "Lunsford for Senate."

\section{The Horserace}

Clearly, the most important issue in the race was jobs and related to it were issues of funding for Kentucky's universities, infrastructure, farmers, and cities. Although the Iraq war was an important issue of the presidential campaign, Lunsford could not have exploited it because Kentuckians backed 
the Republican war line more than most other states. Clearly, the economy mattered most to Kentuckians in the fall of 2008 and McConnell's voting record in support of President Bush's fiscal policies made him vulnerable. Lunsford's support peaked twice - once in May after he won the primary and, more tellingly, toward the end of October when the first Wall Street bailout dominated the news (Table 1). At that point, Senator McConnell still held a 51 percent to 44 percent lead on Lunsford, with 5 percent undecided, according to an October 28 Rasmussen Reports telephone survey of voters in the state. ${ }^{34}$ Just the previous week, McConnell was ahead by several points, however. As the fall continued, the race went up and down.

Yet, as said earlier, Kentucky has split ticket tendencies. So, it is revealing that at a bad time for Republicans across the country other surveys showed 25 percent of Kentucky Democrats still backed McConnell, while 13 percent of Republicans backed Lunsford. McConnell also had a nine-point edge among unaffiliated voters. He led among men by five points and among women by eight. And, tellingly, while Barack Obama garnered almost all of the African-American vote in Kentucky, McConnell still managed to get the backing of 18 percent of those polled. ${ }^{35}$ National political

\section{Table 1. Polling Trends for KY Senate Race in 2008}

\begin{tabular}{|c|c|c|c|c|c|}
\hline Poll & Date & Sample & McConnell & Lunsford & Spread \\
\hline SurveyUSA & $10 / 29-11 / 01$ & $616 \mathrm{LV}$ & 53 & 45 & McConnell +8 \\
\hline Rasmussen & $10 / 29-10 / 29$ & $500 \mathrm{LV}$ & 51 & 44 & McConnell +7 \\
\hline Research 2000 & $10 / 27-10 / 29$ & $600 \mathrm{LV}$ & 47 & 44 & McConnell +3 \\
\hline Rasmussen & $10 / 21-10 / 21$ & $500 \mathrm{LV}$ & 50 & 43 & McConnell +7 \\
\hline Research 2000 & $10 / 19-10 / 21$ & $600 \mathrm{LV}$ & 47 & 43 & McConnell +4 \\
\hline SurveyUSA & $10 / 18-10 / 20$ & $535 \mathrm{LV}$ & 48 & 48 & Tie \\
\hline Research 2000 & $10 / 14-10 / 16$ & $600 \mathrm{LV}$ & 46 & 42 & McConnell +4 \\
\hline Rasmussen & $09 / 30-09 / 30$ & $500 \mathrm{LV}$ & 51 & 42 & McConnell +9 \\
\hline SurveyUSA & $09 / 21-09 / 22$ & $672 \mathrm{LV}$ & 49 & 46 & McConnell +3 \\
\hline Research 2000 & $09 / 15-09 / 17$ & $600 \mathrm{LV}$ & 50 & 37 & McConnell +13 \\
\hline SurveyUSA & $08 / 09-08 / 11$ & $636 \mathrm{LV}$ & 52 & 40 & McConnell +12 \\
\hline Research 2000 & $07 / 28-07 / 30$ & $600 \mathrm{LV}$ & 49 & 38 & McConnell +11 \\
\hline Rasmussen & $07 / 29-07 / 29$ & $500 \mathrm{LV}$ & 52 & 42 & McConnell +10 \\
\hline Rasmussen & $06 / 25-06 / 25$ & $500 \mathrm{LV}$ & 48 & 41 & McConnell +7 \\
\hline SurveyUSA & $06 / 13-06 / 16$ & $626 \mathrm{LV}$ & 50 & 46 & McConnell +4 \\
\hline Rasmussen & $05 / 22-05 / 22$ & $500 \mathrm{LV}$ & 44 & 49 & Lunsford +5 \\
\hline Research 2000 & 05/07-05/09 & $600 \mathrm{LV}$ & 48 & 36 & McConnell +12 \\
\hline \multicolumn{6}{|c|}{$\begin{array}{l}\text { Source: Adapted from Real Clear Politics, Kentucky Senate 2008, http://www.realclearpolitics.com/ } \\
\text { epolls/2008/senate/ky/kentucky_senate-917.html (accessed April 1, 2009). } \\
\text { LV = Likely voters }\end{array}$} \\
\hline
\end{tabular}


analysts who followed public opinion closely showed McConnell ahead in the early part of the race with Lunsford closing the gap toward the end. For example, Larry Sabato's Crystal Ball Website entries over the course of the 2008 election showed weaker support for McConnell as the year went on. Rothenberg Political Reports put McConnell ahead narrowly while Rasmussen was more favorable to him throughout the election cycle. ${ }^{36}$ There was never prediction of an easy upset.

\section{Money: Record-Breaking Warchests}

Mitch McConnell built a substantial war chest well in advance, as he had done in previous races, and had \$7.7 million on hand at the time Lunsford won the primary in May (Table 2). According to the Center for Responsive Politics, McConnell's contributions from political action committees (PACs) were around a quarter of his total financing while Lunsford's were much less-around 4 percent. McConnell's campaign war chest was dominated by individual contributions at 60 percent with about 16 percent coming from self-financed contributions and $\$ 2$ million in bank loans. When polls showed the race tightening beginning in late September, these loans got a lot of local press attention as McConnell financed a blizzard of new television ads in the final weeks of the campaign in response to the Democratic Senatorial Campaign Committee's infusion of ads and money in support of Lunsford. $^{37}$

Mr. Lunsford's campaign raised over $\$ 7$ million on its own and benefited from almost $\$ 3.5$ million from the DSCC, which ranked him eighth out of eighteen races supported this way by the Democrats, ranging from $\$ 1.5$ to 12.5 million (independent expenditures from the National Republican Senatorial Committee were negligible). ${ }^{38}$ Lunsford's individual contributions were only 16 percent with the bulk ( 80 percent) of his campaign finance funded by the category "other," which in this case meant loans from Lunsford to the campaign. The Kentucky Senate race was the most expensive in

Table 2. Campaign Finance Summaries for KY Senate Race 2008

\begin{tabular}{lrrr}
\hline & McConnell & \multicolumn{1}{c}{ Lunsford } & \multicolumn{1}{c}{ Total } \\
\hline Receipts & $\$ 20,991,678$ & $\$ 10,883,172$ & $\$ 31,874,850$ \\
Disbursements & $\$ 21,334,523$ & $\$ 10,801,203$ & $\$ 32,135,726$ \\
Cash on Hand & $\$ 87,972$ & $\$ 81,967$ &
\end{tabular}

Source: Center for Responsive Politics, http://www.opensecrets.org/races/summary.php?cycle= 2008\&id=KYS1 (accessed April 10, 2009). 
state history and, at more than $\$ 31$ million for both sides, was the nation's second most expensive Senate race, according to the Center for Responsive Politics, with the Minnesota Senate contest at the top. ${ }^{39}$

The totals on both sides imply that McConnell knew he was in trouble. One Louisville columnist in his year-end summary of political life in the state in 2008 explained that all of McConnell's funds, especially the extra \$2 million were necessary and well-used. "Polls showed McConnell and Lunsford about neck-and-neck a month before the election, but McConnell used the millions he raised and borrowed wisely and was able to pull out a 6point win., 40

\section{Impact of the 2008 Presidential Contest}

In the presidential election Kentucky was never in play. So it is not surprising the state barely got a dozen total visits from all top Democratic and Republican candidates combined. Barack and Michelle Obama each visited only once (just before the May 20 primary). However, Hillary, Bill, and Chelsea Clinton visited several parts of the state before the primary, which Clinton won by a large margin as predicted. In the early part of the campaign, Sen. McCain visited Kentucky twice-in April as part of his "poverty tour" and in May to address the National Rifle Association convention in Louisville. ${ }^{41}$ In the general election, McCain visited once more and Vice President Biden also visited Kentucky just once, in September, for a fundraising dinner. Sarah Palin never visited Kentucky at all; however, both vice presidential candidates visited nearby Indiana in the fall and received news coverage and visitors from across the Ohio River in Louisville. ${ }^{42}$ The Obama campaign had some presence in the largest metropolitan areas in the weeks before the primary, but no dominant force before the general election. Obama's campaign had a Kentucky page on his general election website, but it was not personalized to the state in any dramatic manner. ${ }^{43}$

The most obvious fact about Kentucky's presence in the 2008 presidential election drama was that that Kentucky was pegged as a solid GOP state the entire cycle, especially after Barack Obama won the nomination. Kentucky was one of only seven states that did not hand Obama either a primary or general election victory. ${ }^{44}$ Significant shifts occurred in Kentucky at the end of the race that favored McCain, even as McCain's fortunes suffered elsewhere. Over the month of October, McCain increased his support from an 8 to 10 to 12 percentage lead over Barack Obama, ending the month up 55-43, which was his highest showing against Obama for five months, according to Rasmussen Reports. Part of this jump was attributed to unaffiliated voters leaning heaving toward McCain. In late October, Rasmussen polling in Kentucky showed McCain leading by just 4 points among 
men in Kentucky. Just 5 days before election day this jumped to 58 percent to 39 percent among men (compared to $52 \%$ to $47 \%$ among women). A lopsided racial disparity continued, with white voters choosing McCain over Obama by a 59 percent to 40 percent margin and black voters overwhelmingly backing Obama, 90 percent to 10 percent. Bucking the national trends at the end of the presidential race, Kentucky voters trusted McCain over Obama by 11 points on the economy. Unaffiliated voters in the state trusted the Republican even more, 55 percent to 37 percent. Voters in Kentucky also gave McCain the edge on national security by 22 points. ${ }^{45}$

As said above, these numbers did not reflect a great affection for McCain as much as a deep dislike and/or distrust of Obama that negatively impacted Bruce Lunsford's chances. One senior field organizer for Lunsford said in an interview that campaign phone and door-to-door workers were explicitly instructed to downplay Lunsford's affiliation with Obama as much as possible if asked. The prevailing mode in the Lunsford campaign was to avoid mentioning or discussing the presidential nominee completely. Lunsford's extensive TV ad campaign did not mention Barack Obama or feature his image, words, or other evidence of a coattails strategy. In television news interviews, Lunsford argued repeatedly that voters could separate the offices on the ballot as they had done in the past. Each of the campaign professionals interviewed for this article suggested (unsolicited) that race played a large factor in most rural counties' voting behavior and if Hillary Rodham Clinton had been the Democratic nominee, she might have won Kentucky or at least gotten closer to winning than Obama. Likewise, if Lunsford were listed below Clinton on the ballot, he would have fared better and could have won.

\section{Why McConnell Wins by a Length}

McConnell's victory speech the night of his re-election began with a quotation. "Winston Churchill once said that the most exhilarating feeling in life is to be shot at - and missed. After the last few months, I think what he really meant to say is that there's nothing more exhausting. This election has been both." ${ }^{46}$ The race was intense and expensive because McConnell had to prove himself worthy of the seat for the first time in decades and Republicans nationally had to "play defense" in the wake of the unpopular outgoing president. Although this race, like all others, is best understood in the state's multi-layered political and cultural contexts, there are aspects of the race that lend insights into voting and political behavior more generally.

In Kentucky, McConnell swam successfully against the national tide because he spoke the language of representation: Kentucky is a poor state and relies openly on federal assistance in both urban and rural areas, from 
the state universities' elite researchers to unemployed blue-collar families to insecure farmers. McConnell's Washington career and campaign themes have long centered on political clout for Kentucky. Separating himself from the woes of his party, McConnell's personal brand is defined by an economic connection to all parts of the state. This relationship is continuous, demanding, and sets clear rules for each side: support for McConnell will result in some form of federal assistance. ${ }^{47}$ A week after the election, an editorial in The Hazard Herald reminded McConnell not to forget the economically disadvantaged East.

\begin{abstract}
While we realize that Sen. McConnell has a number of duties to attend to in Washington while being the leader of his party in the Senate, there are a myriad of responsibilities right here in his own state that need attending to as well. ... The senator from Louisville campaigned on the power he wields in Washington, and he has again gained the majority of votes from his home state. Now is not the time to rest with the knowledge that another six years have been gained, but to put into action the words heard on the campaign trail. The people deserve no less. ${ }^{48}$
\end{abstract}

In this story of power and representation, there is also a lesson for political challengers. Lunsford did better than any other challenger to McConnell since 1990, but left some wondering if he had turned over every stone. Lunsford did not exploit McConnell's vulnerabilities and he had to play defense himself because his prior business practices were a distracting issue. In an election post-mortem, a columnist for the Lexington HeraldLeader said Lunsford failed to hammer McConnell on three specific issues: McConnell's close relationship with the deeply unpopular (even in presidential "red" Kentucky) President Bush, McConnell's non-hesitant support for the $\$ 700$ billion October financial industry bailout, and McConnell's personal and political closeness to Senator Ted Stevens, who was at that time recently convicted of three federal felony counts just before the election. The columnist wondered if Lunsford's not being the top choice for Democrats meant that perhaps the others would have done it better. ${ }^{49}$ Top strategists on both sides said in interviews that Lunsford's main reason for running was his "ego" and need to erase the previous losses. Personal wealth and good timing appeared to not be a match against a dyed-in-wool politician.

McConnell fought off Lunsford by emphasizing his representative credentials and downplaying his national connections. He admitted as much after the election was over, seeming thankful that he survived the tough election year. Senator McConnell said in January, 2009, on the Today Show: "Well, I was a strong supporter of the President [Bush], but presidential unpopularity is bad for the president's party. We suffered losses in ' 06 and ' 08 . We wish President Bush well. But frankly, [in 2010] we will not have to be 
carrying that sort of political burden that we carried the last two elections.. 50 Luck and timing played into it too: if Bunning and McConnell's election schedule had been reversed, Bunning would likely be out.

Above all else, the campaign professionals interviewed agreed that McConnell is deeply tuned into his strengths and weaknesses. Rural and small town voters know he is not one of them - not a farmer, son of a coal miner, nor does he have extensive military experience. He does not have a symbolic/descriptive representative mindset (see Pitkin 1967) — nor do they. These voters are old fashioned enough to want the candidate to justify their record and solicit support face-to-face. In 2008, McConnell went county by county on the stump. It's about substance: what did you do for me lately? Nationally, Democrats were hoping to unseat the party leader, as happened to Tom Daschle (D-SD) in 2004 and Rep. Tom Foley (D-WA) in 1994. McConnell was tuned into that vulnerability when he said on the campaign trail "unlike six years ago, it's not going to be a coronation. It was fun getting 65 percent of the vote and carrying 113 out of 120 counties [in 2002]. That was then, and this is now. And what is different is that your senator is a lot bigger target than he used to be. ${ }^{, 51}$

\section{NOTES}

${ }^{1}$ Jack Brammer and Beth Musgrave, "McConnell Blames Tight Race on Left," Lexington Herald-Leader (KY), October 21, 2008, http://www.kentucky.com/181/story/ $\underline{562710 . h t m l}$.

"'Bruce Lunsford: Campaign for Change," http://www.youtube.com/user/ BruceLunsford2008.

${ }^{3}$ For a comprehensive review of key concepts and literature in the study of representation see http://plato.stanford.edu/entries/political-representation/.

${ }^{4}$ This kind of delicate dance between national partisanship and district focus in Congress is a key to long-term electoral and political success (see Mayhew 1974 among others).

${ }^{5}$ See for example different spots that showcased federal appropriations for Louisville (http://www.youtube.com/watch? $\mathrm{v}=\mathrm{PFgRK19}-\mathrm{MIM} \&$ feature=channel), Northern Kentucky (http://www.youtube.com/watch?v=Rbi265Q8omE\&feature=channel), and Central Kentucky (http://www.youtube.com/watch?v=mi- aZz5oGw\&feature=channel).

${ }^{6} \mathrm{http}: / /$ www.youtube.com/watch? $\mathrm{v}=\mathrm{KHCcLHooVM} \&$ feature=related.

${ }^{7}$ For McConnell approval data, see http://www.ourcampaigns.com/CandidateDetail. html?CandidateID $=41 \&$ ShowAllPoll $=\mathrm{Y}$ and Rasmussen Reports, October 28, 2008, http://www.rasmussenreports.com/public content/politics/election_20082/2008 senate elections/kentucky/election 2008 kentucky senate.

${ }^{8}$ The Association of Religion Data Archives, Evangelical Protestant States (2000), http://www.thearda.com/QuickLists/QuickList 64.asp.

${ }^{9}$ Frank Newport, "Church Attendance Lowest in New England, Highest in South," Gallup, http://www.gallup.com/poll/22579/Church-Attendance-Lowest-New-EnglandHighest-South.aspx. 
${ }^{10}$ See Republican National Committee, 2008 Platform, "Values" Section, http:// www.gop.com/2008Platform/Values.htm; Guttmacher Institute, State Facts about Abortion: Kentucky, http://www.guttmacher.org/pubs/sfaa/kentucky.html; CNN.com Election Results: Ballot Measures, November, 2004, http://www.cnn.com/ELECTION/2004/ pages/results/ballot.measures/; Brady Campaign to Prevent Gun Violence, Kentucky Gun Laws: Brady State Scorecard 2008, http://www.stategunlaws.org/viewstate.php?st=KY; Behavioral Risk Factor Surveillance System study, as reported in the Washington Post, May 26, 2006, http://www.washingtonpost.com/wp-srv/health/interactives/guns/ownership.html.

${ }^{11}$ http://www.lrc.ky.gov/orgadm.htm (accessed April 13, 2009).

${ }^{12}$ SurveyUSA, Survey News Poll 11478, December, 2006, "Do you approve or disapprove the job Ernie Fletcher is doing as Governor?" http://www.surveyusa.com/client/ PollReport.aspx?g=a3755e2c-daa4-4239-a0f0-748f3d0ae28e.

${ }^{13}$ See http://elect.ky.gov/NR/rdonlyres/1283C01A-3F26-4821-8336-5878446F15E4/ 173402/STATE.TXT for official Kentucky election outcomes and http://www.cnn.com/ ELECTION/2008/results/individual/\#mapSKY for additional data.

${ }^{14}$ SurveyUSA, Presidential Approval, Adults in Kentucky, May, 2005 through December, 2008, http://www.surveyusa.com/client/PollTrack.aspx?g=eaaa48ca-87704081-b879-faaced5ac45a.

${ }^{15}$ Text of Senator McConnell's election night victory speech, http://www.wave3.com/ Global/story.asp?S=9294377.

${ }^{16}$ See Ourcampaigns.com for details about Senator McConnell's political resume, http://www.ourcampaigns.com/CandidateDetail.html?CandidateID=41.

${ }^{17}$ While it was a good year for some Republicans due to President Reagan's landslide re-election, McConnell was personally credited with winning due, in part, to his campaign's two versions of an original television ad that showed a pack of sniffing bloodhounds questioning the Washington whereabouts and voting record of Sen. Huddleston. The "hounds" ad campaign went immediately and deeply into Kentucky political lore-so much so that Bruce Lunsford's campaign in 2008 used the exact concept against Sen. McConnell, down to the running dogs, a bearded man in a flannel shirt holding the leashes, and a suited man representing the incumbent going up a tree. See two different "bloodhound" ads from the 1984 campaign, http://www.youtube.com/watch? $v=$ $\underline{\mathrm{K} 4 \mathrm{KOhlZR} 9 \mathrm{~s} \& \text { feature=related and } \mathrm{http}: / / \text { www.youtube.com/watch?v=T4-4EPc2xvU }}$ $\underline{\& \text { feature }=\text { related and Lunsford's reversal of the bloodhound trail in } 2008 \mathrm{http}: / / \mathrm{www}}$. youtube.com/watch?v=rC8QSGvRDLE.

${ }^{18}$ For a variety of vote and issue positions, see http://www.sourcewatch.org/index. php?title=Mitch_McConnell.

${ }^{19}$ Halimah Abdullah, "Profile of Mitch McConnell: Versed in the Ways of Power," Lexington Herald-Leader (KY), October 21, 2008, http://www.kentucky.com/181/story/ 562661.html.

${ }^{20}$ See http://www.ontheissues.org/senate/Bruce Lunsford.htm and http://en. wikipedia. org/wiki/Bruce Lunsford.

${ }^{21}$ Patrick Crowly, "Lunsford's Party Loyalty May be Issue," Kentucky Enquirer, February 26, 2007, posted at http://news.cincinnati.com/apps/pbcs.dll/article?AID= /20070226/NEWS0103/702260362/1077/COL02.

${ }^{22}$ See http://www.ontheissues.org/senate/Bruce Lunsford.htm.

${ }^{23}$ Jack Brammer, "Profile of Bruce Lunsford: Real Rags-to-Riches Tale," Lexington Herald-Leader (KY), October 20, 2008, http://www.kentucky.com/181/story/561558 .html.

${ }^{24}$ http://www.youtube.com/watch?v=vPqLOYd j-s. 
${ }^{25} \mathrm{http}: / /$ www.youtube.com/watch?v=GMCoTR2Y8RU.

${ }^{26}$ Jill Laster, Candidate Profile: Bruce Lunsford, Kentucky Kernel, October 30, 2008, http://kykernel.com/2008/10/30/candidate-profile-bruce-lunsford/.

${ }^{27}$ http://www.youtube.com/watch?v=0JVJIvSfxIQ.

${ }^{28} \mathrm{http} / / /$ www.youtube.com/watch?v=FkG4JpXGXoA.

${ }^{29}$ Rasmussen Reports, 2008 Election: Kentucky Presidential Election, October 28, 2008, http://www.rasmussenreports.com/public_content/politics/election_20082/2008 presidential_election/kentucky/election_2008 kentucky presidential_election.

${ }^{30} \mathrm{http}: / / \mathrm{www}$. youtube.com/watch? $\mathrm{v}=\mathrm{jidL} 3 \mathrm{Q}$ JbeA.

${ }^{31}$ http://www.cnn.com/ELECTION/2008/results/polls/\#KYS01p1 exit polling issues.

${ }^{32}$ Trey Pollard, "Top Democrats Praise Lunsford in Louisville," PolitickerKy.com, June 13, 2008, http://www.politicker.com/kentucky/6488/top-democrats-praise-lunsfordlouisville.

${ }^{33}$ Halimah Abdulla, "Election Precedent Set-Senate, Presidential Fund-Raising Break Records," Lexington Herald-Leader (KY), November 9, 2008.

${ }^{34}$ Rasmussen Reports, October 28, 2008, http://www.rasmussenreports.com/ public content/politics/election_20082/2008 senate_elections/kentucky/election_2008 kentucky senate.

${ }^{35}$ Rasmussen Reports, 2008 Election: Kentucky Presidential Election, October 28, 2008, http://www.rasmussenreports.com/public_content/politics/election_20082/2008 presidential_election/kentucky/election 2008 kentucky presidential election.

${ }^{36}$ Larry J. Sabato's Crystal Ball, Senate Outlook for 2008, http://www.centerfor politics.org/crystalball/2008/senate/?state=KY; Rasmussen Reports, October 28, 2008, http://www.rasmussenreports.com/public_content/politics/election_20082/2008 senate elections/kentucky/election 2008 kentucky senate; The Rothenberg Political Report, Kentucky Senate: Ratings Change Favors Democrat, September 29, 2008, http://rothenbergpoliticalreport.blogspot.com/2008/09/kentucky-senate-ratings-change-favors.html.

${ }^{37}$ Joseph Gerth, "McConnell \$2 Million in Debt," The Courier-Journal (Louisville, KY), December 7, 2008.

${ }^{38}$ A First Look at Money in the House and Senate Elections, November 6, 2008, Campaign Finance Institute, George Washington University, Table 6: All Senate Races, 2008, http://www.cfinst.org/congress/pdf/Table6 PostElec.pdf; A First Look at Money in the House and Senate Elections, November 6, 2008, Campaign Finance Institute, George Washington University, Table 7: Independent Expenditures by National Party Committees in the 2008 Congressional General Election (Reported through November 3, 2008), http://www.cfinst.org/congress/pdf/Table7_PostElec.pdf.

${ }^{39}$ Halimah Abdullah, "McConnell Campaign in Debt-Nearly \$2 Million Borrowed for 2008 Run," Lexington Herald-Leader (KY), December 10, 2008.

${ }^{40}$ Joseph Gerth, "Political Notebook: A Look Back at What 2008 Brought Kentucky," The Courier-Journal (Louisville, KY), December 29, 2008.

${ }^{41}$ For news summaries of both visits, see http://www.reuters.com/article/topNews/ idUSN2343192120080423 and http://www.youtube.com/watch?v=juwXH3P0NXg.

${ }^{42}$ http://www.gwu.edu/ action/2008/obama/bidenstatevisits.html and http://www. gwu.edu/ action/2008/mccain/palinstatevisits.html.

${ }^{43}$ http://my.barackobama.com/page/content/kyhome.

${ }^{44}$ Joseph Gerth, "Political Notebook: A Look Back at What 2008 Brought Kentucky," The Courier-Journal (Louisville, KY), December 29, 2008. 
${ }^{45}$ Rasmussen Reports, 2008 Election: Kentucky Presidential Election, October 28, 2008, http://www.rasmussenreports.com/public_content/politics/election_20082/2008 presidential election/kentucky/election 2008 kentucky presidential election.

${ }^{46}$ Text of Senator McConnell's election night victory speech, http://www.wave3. com/Global/story.asp?S=9294377.

${ }^{47}$ Jill Laster, Candidate Profile: Mitch McConnell, Kentucky Kernel, October 30, 2008, http://kykernel.com/2008/10/30/candidate-profile-mitch-mcconnell/\#more-7325.

${ }^{48}$ Editorial, "It's Time to use Some of that Clout," The Hazard Herald (KY), November 12, 2008.

${ }^{49}$ Larry Dale Keeling, “Lunsford, Dems Missed Chance to 'Ditch Mitch'-Didn't Hit McConnell on Bush, Economy, Stevens," Lexington Herald-Leader (KY), November 9, 2008.

${ }^{50} \mathrm{http}: / /$ thinkprogress.org/2009/01/27/mcconnell-bush-burden/.

${ }^{51}$ Jack Brammer and Beth Musgrave, "McConnell Blames Tight Race on Left," Lexington Herald-Leader (KY), October 21, 2008, http://www.kentucky.com/181/story/ $\underline{562710 . h t m l}$.

\section{REFERENCES}

Carson, Jamie L. 2005. Strategy, Selection, and Candidate Competition in U.S. House and Senate Elections. The Journal of Politics 67(1):1-28.

Herrnson, Paul S. 2004. Congressional Elections: Campaigning at Home and in Washington, 4th ed. Washington, DC: CQ Press.

Jacobson, Gary C. 1980. Money in Congressional Elections. New Haven, CT: Yale University Press.

Jacobson, Gary C. 1985. Money and Votes Reconsidered: Congressional Elections, 19721982. Public Choice 47:7-62.

Karp, Jeffrey A. and Marshall W. Garland. 2007. Ideological Ambiguity and Split Ticket Voting.. Political Research Quarterly 60(4):722-732.

Mayhew, David R. 1974. Congress: The Electoral Connection. New Haven, CT: Yale University Press.

Pitkin, Hanna. 1967. The Concept of Representation. Berkeley: University of California Press. 